\title{
Toxoplasmosis in Germany
}

\author{
Epidemiology, Diagnosis, Risk factors, and Treatment \\ Uwe Pleyer, Uwe Gross, Dirk Schlüter, Henrik Wilking, Frank Seeber
}

Department of Ophthalmology, Charité Campus Virchow, University Faculty of Medicine, Berlin, Corporate Member of Freie Universität Berlin, HumboldtUniversität zu Berlin, and Berlin Institute of Health: Prof. Uwe Pleyer

Institute of Medical Microbiology and German Reference Laboratory for

Toxoplasma Infection, Faculty of Medicine University of Göttingen: Prof. Uwe Groß Institute of Medical Microbiology and Hospital Epidemiology, Hannover Medical School (MHH): Prof. Dirk Schlüter

Unit 35: Gastrointestinal Infections, Zoonoses and Tropica Infections, Robert Koch Institute, Berlin: Dr. Hendrik Wilking

Unit 16: Mycotic and parasitic agents and mycobacteria, Robert Koch Institute, Berlin Prof. Frank Seeber

\section{Summary}

Background: With approximately $30 \%$ of the world population infected, Toxoplasma gondii is one of the most widespread pathogenic parasites in both humans and animals and a major problem for health economics in many countries.

Methods: This review is based on the findings of individual studies, meta-analyses, and Cochrane Reviews retrieved by a selective literature survey of the Medline and Google Scholar databases.

Results: Current data indicate a high rate of Toxoplasma gondii infection in Germany, ranging from $20 \%$ to $77 \%$ depending on age (95\% confidence interval for 18- to 29-year-olds [17.0; 23.1]; for 70- to 79-year-olds [72.7; 80.5]). Male sex, caring for a cat, and a body mass index of 30 or more are independent risk factors for seroconversion. Postnatally acquired (food-related) infection is predominant, but maternal-to-fetal transmission still plays an important role. While most infections are asymptomatic, congenital toxoplasmosis and reactivated Toxoplasma encephalitis in immunosuppressed persons (transplant recipients and others) are sources of considerable morbidity. Toxoplasma gondii infection of the retina is the most common cause of infectious uveitis in Germany. The diagnosis and treatment of this type of parasitic infection are particular to the specific organs involved in the individual patient.

Conclusion: Desirable steps for the near future include development of an effective treatment for the cystic stage and identification of biomarkers to assess the risk of reactivation and predict the disease course.

\section{Cite this as:}

Pleyer U, Gross U, Schlüter D, Wilking H, Seeber F: Toxoplasmosis in Germany_epidemiology, diagnosis, risk factors, and treatment. Dtsch Arztebl Int 2019; 116: 435-44. DOI: 10.3238/arztebl.2019.0435

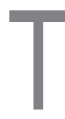
oxoplasma gondii is an extremely successful protozoan parasite that infects about one-third of the world's population (1). The World Health Organization (WHO) estimates that, in Europe, $20 \%$ of the burden of disease transmitted through food is caused by T. gondii infection (2). The life cycle of this single-cell organism is complex. In humans, the main oral source of infection is believed to be eating or handling inadequately cooked or raw meat containing tissue cysts (bradyzoites), or consuming fruit, vegetables, or water contaminated with oocysts ("spores") (3) (Figure 1). Because of the risk of mother-to-child transmission, these zoonotic routes of infection are particularly important in cases where a woman is infected for the first time during pregnancy (4). In addition to congenital toxoplasmosis, reactivated Toxoplasma encephalitis in immunosuppressed patients (e.g., those with AIDS or

\section{Definition}

Toxoplasma gondii is a protozoan parasite that infects about one-third of the world's population. under heavy immunosuppression following stem cell or organ transplantation) and ocular toxoplasmosis are clinically significant manifestations of this disease (Figure 1). If disability-adjusted life years (DALY) per case are taken as a measure of the severity of disease, in Europe, congenital toxoplasmosis , at 2.42 DALYs per case [95\% confidence interval (CI): 1.92; 3.05], is on a level with hepatitis B $(2.79[1.46 ; 4.45])$ and invasive pneumococcal infection $(2.74[2.71 ; 2.77])$, and ranks ahead of tetanus infection $(2.02[1.91 ; 2.15])$ (e1). According to the WHO, toxoplasmosis is an important public health issue $(4, e 2)$. In 2016, as part of a study of adult health in Germany (DEGS1), the Robert Koch Institute surveyed T. gondii seroprevalence among adults in Germany for the first time (5) and found it to be $49.1 \%$.

The present article is based on a literature search using the search terms "diagnosis," "encephalitis," 
FIGURE 1
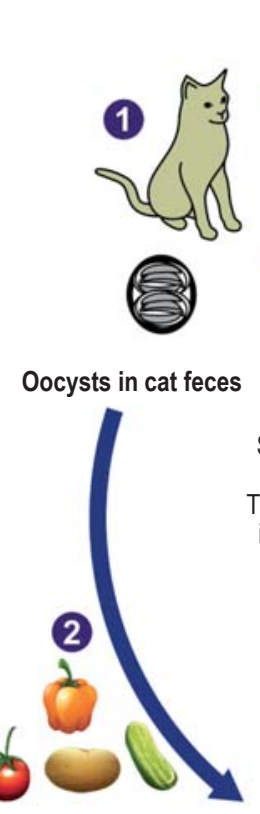

Natural infection cycle

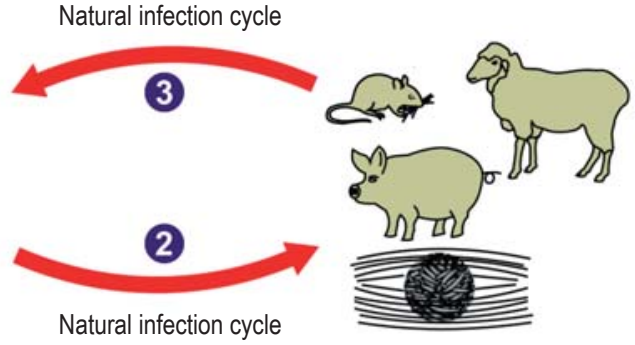

Tissue cysts in meat

Soon after ingestion, oocysts and tissue cysts transform into tachyzoites. The tachyzoites multiply in various organs including neural and muscle tissue, and develop into tissue cysts containing bradyzoites.

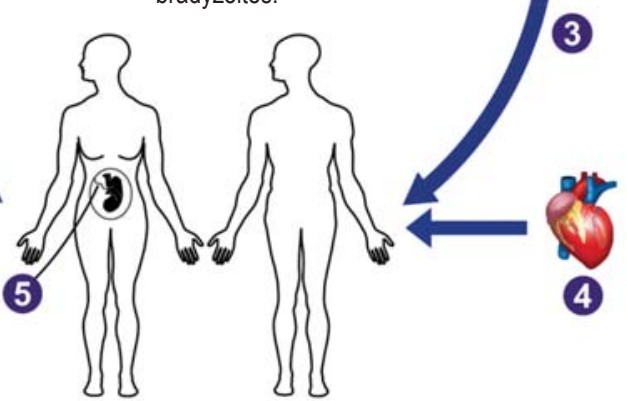

1
2
3
4
5

Sexual reproduction in cat gut (definitive host)

2 Oral infection via vegetables, water, etc. contaminated with oocysts

3 Oral infection via undercooked meat or raw meat products

4 Infection from infected transplants

(5) Diaplacental infection

T. gondii infection cycle (simplified).

The infective pathogen is transmitted in the form of oocysts (spores) excreted in the feces of infected cats (1). Thus, T. gondii can be transmitted to domestic animals and rodents as well as to humans via contaminated food (2). Cats acquire the infection via tissue cysts (bradyzoites = chronic, slowly multiplying stage of the parasite) when they eat, for example, infected rodents (3). The same occurs in humans through consumption of undercooked meat from infected animals (3). Transplantation of tissue from infected persons (4) and diaplacental transmission (5) during a first infection in a pregnant woman are additional routes of infection. The acute, rapidly replicating intracellular tachyzoite stage spreads within infected organisms before transforming into bradyzoites (adapted from [e3]). “epidemiology,” “pregnancy, “seroprevalence," "therapy," "toxoplasmosis," and "uveitis."

\section{Learning goals}

After reading this article, the reader should:

- Know the routes of infection, epidemiology, and risks of this parasitic infection

- Have a good grasp of the clinical features, organ manifestations, and sequelae of the infection

- Understand the rationale of the preventive measures and treatment options for $T$. gondii infection

\section{Epidemiology}

In Germany, T. gondii infections in humans are probably acquired mainly through the consumption of pork in raw sausage products (Rohwurst, Mettwurst) (5). To date there have been no reports in Germany of outbreaks caused by contaminated drinking water or surface water $(e 4, e 5)$. Oocysts have also been shown to be present in air samples, so infection via the airways cannot be ruled out (e6). The influence of eating habits and food hygiene is reflected in current epidemiological data and serosurveys on infection rates. The latter are an important surrogate in the search for information about the prevalence of infection. Seroconversion rates vary greatly around Europe, ranging from $7 \%$ to $10 \%$ in Norway and the United Kingdom to $44 \%$ and $50 \%$ in France and Germany respectively $(5, \mathrm{e} 7)$. In adults in Germany (18 to 79 years of age), the seroprevalence of IgG antibodies against $T$. gondii is almost $50 \%$, rising in an almost linear fashion ( $1 \%$ per year) from about $20 \%$ in young adults (18 to 29 years) to $77 \%$ in the 70 - to 79 -year-old age group (5). Men, cat owners, and the obese $(\mathrm{BMI} \geq 30)$ were more often seropositive. Vegetarian eating habits and high socioeconomic status were found to be preventive factors.

Modeling on the basis of this data suggests that every year about 6390 infections occur during pregnancy, and that an estimated 345 neonates will be clinically symptomatic (5). This is far higher than the number of children with congenital toxoplasmosis reported annually to the Robert Koch Institute (between 6 and 38); the discrepancy may be explained by considerable under-reporting and/or abortions caused by unidentified infection. At the same time, these numbers confirm the importance of this zoonosis for public health (4) (Figure 2).

\section{Pathogenesis and pathology}

The pathophysiology and clinical course of toxoplasmosis are largely determined by the complex life cycle

\section{Epidemiology}

\section{Infection cycle}

$T$. gondii is transmitted in the form of oocysts (spores) excreted in the feces of infected cats. Thus, $T$. gondii can be transmitted to domestic animals and rodents as well as to humans via contaminated food.
In Germany, T. gondii infections in humans are probably acquired mainly through the consumption of pork in raw sausage products. To date there have been no reports in Germany of outbreaks caused by contaminated drinking water or surface water. 

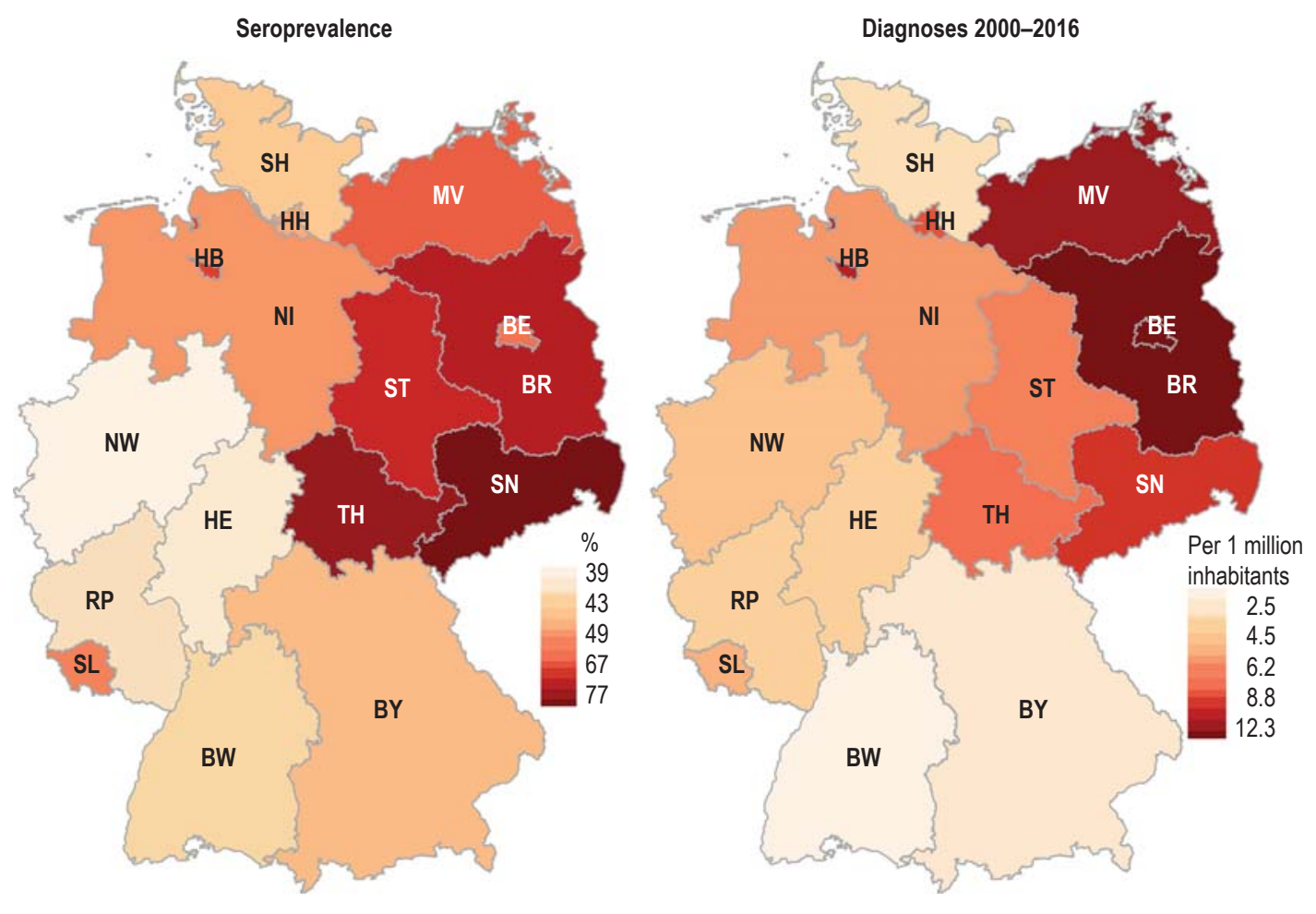

The seroprevalence of $T$. gondii in the federal states of Germany in 2008 (left) and cumulative data on $T$. gondii-related diagnoses for the period 2000 to 2016 (right). The markedly higher seroprevalence in the eastern part of the country is probably due to the much higher consumption of raw pork mince and raw sausage in those states (5), as has been observed for other infectious diseases transmitted through the consumption of meat (e.g., yersiniosis) (e8, e9). Based on the analysis of hospital data on diagnoses (per 1 million head of population) from 2000 to 2016 (available at www.gbe-bund.de), using the ICD-10 four-digit codes for toxoplasmosis (B58), it can be seen that billing figures are also much higher in the eastern states. It may be concluded from this that the higher seroprevalence in eastern Germany appears to be accompanied by a higher disease burden in these states.

BE, Berlin; BR, Brandenburg; BW, Baden-Württemberg; BY, Bavaria; HB, Bremen; HE, Hesse; HH, Hamburg; MV, Mecklenburg-West Pomerania; NI, Lower Saxony; NW, North Rhine-Westphalia; RP, Rhineland-Palatinate; SH, Schleswig-Holstein; SL, Saarland; SN, Saxony; ST, Saxony-Anhalt; TH, Thuringia

of T. gondii, the diversity of its strains, and the immune adaptation of the pathogen (Figure 1) (3). After ingestion of the pathogen, intestinal infection of macrophages and dendritic cells results in hematogenous spread affecting first and foremost neural (brain, eyes) and lymphatic tissue, the heart, and the lungs. In cases of acute infection with lysis of infected host cells, the presence in the blood of extracellular tachyzoites (corresponding to the development stage of a parasite in which acute, rapid replication takes place) can lead to infection of organs and of the placenta as well.

\section{Seroprevalence}

In adults in Germany (18 to 79 years of age), the seroprevalence of IgG antibodies against $T$. gondii is almost $50 \%$, rising in an almost linear fashion (1\% per year) from about $20 \%$ in young adults (18 to 29 years) to $77 \%$ in the 70 -to 79 -year-old age group
Susceptibility and the severity of clinical manifestations are both subject to the interactions of pathogen- and host-specific factors and are the focus of current research (eTable 1). In Europe and North America, about $70 \%$ to $80 \%$ of infections are caused by type II genotype, which is relatively avirulent and in ocular toxoplasmosis, for example, tends to result in a chronic recurrent course. In contrast to this, particularly in South America, the genetic diversity of T. gondii is greater and infections are also caused by type I, type III, and "atypical" (recombinant) genotypes. The 
clinically more serious, often fulminant course with these types is believed to be due to greater rapidity of replication, extracellular migration of the pathogen, and reduced differentiation into bradyzoites $(7, \mathrm{e} 10)$.

The immune system plays an important part in susceptibility and the clinical course of toxoplasmosis (eFigure). While cellular immune mechanisms control the pathogen in infected cells, $T$. gondii-specific antibodies contribute to the neutralization of extracellular tachyzoites, which in women who have been previously infected helps to protect the placenta from infection. With the aid of these immune mechanisms, the pathogen can be eliminated from practically every cell in the body.

However, under the pressure of the immune response, a few parasites in neurons and myocytes transform into bradyzoites and persist intracellularly in tissue cysts. This persistence of the pathogen requires the maintenance of a protective proinflammatory immune response and the development of immunosuppressive and regulatory $\mathrm{T}$ cells. This is particularly important in ocular toxoplasmosis because of the highly sensitive retina, which cannot be regenerated $(7$, e10). Clinical studies indicate that among other factors the balance between IL-17producing $\mathrm{T}$ cells on the one hand and astrocytes and regulatory $\mathrm{T}$ cells on the other is important, because the retina can be damaged not just by the pathogen but also by an IL-17-mediated immune pathology (7). If immunity weakens, the infection can reactivate with renewed tachyzoite replication and tissue necrosis. This manifests clinically both in (immunocompetent) patients with recurrent ocular toxoplasmosis and in AIDS patients with low $\mathrm{CD}^{+}{ }^{+} \mathrm{T}$ cells in the brain. Despite the high prevalence of infection and pathogen persistence, clinically significant reactivated toxoplasmosis occurs only rarely in persons who are receiving strong immunosuppressants, e.g., TNF blockers in patients with ankylosing spondylitis $(8, \mathrm{e} 11, \mathrm{e} 12)$. This may emphasize the importance of local immune mechanisms, but it may also, e.g., in AIDS patients, underline the role being played by the retrovirus itself, with impaired antiparasitic function of HIV-infected microglia.

The close relationship between the immune system and effective parasite control is also shown by studies that have identified genetic polymorphisms as risk factors in genes that are important for immune reactions (eTable 1 ).

\section{Clinical manifestations of toxoplasmosis}

In most cases toxoplasmosis is asymptomatic or accompanied by mild flu-like symptoms. Fewer than
$10 \%$ of infected persons develop a mononucleosis-type pattern of symptoms including fever, headache, and aching limbs, along with lymphadenitis, especially of the cervical and occipital lymph nodes. These become hard, tender to the touch, and may remain swollen for several weeks. In a few cases, an uncharacteristic maculopapular rash, reactive arthritis, or organ findings such as hepatosplenomegaly, myocarditis, or pneumonia have been observed $(1,6)$.

Clinically significant manifestations include congenital and ocular toxoplasmosis and, in immunosuppressed patients, organ manifestations that can often be life-threatening (encephalitis, pneumonia) (4, 15-17).

\section{Congenital infection}

The WHO estimates the global annual incidence of congenital toxoplasmosis at about 190100 cases and considers it an underestimated burden of disease with considerable sequelae (4). In Germany, between 6 and 38 cases a year are notified to the Robert Koch Institute (https://survstat.rki.de) in accordance with the Infection Protection Act (IfSG, Infektionsschutzgesetz). However, since only a minority of infected children show any clinical abnormality at birth, and only these cases are reported, the real number must be considerably higher. In fact, computer modeling suggests that more than 1200 congenitally infected children are born in Germany every year (5). Placental transmission is a risk only when the first infection occurs during a pregnancy; during a second or later infection, antibodies that persist throughout life opsonize the parasites, leading to antibody-mediated phagocytosis. Rare circumstances in which transmission can occur during pregnancy include reactivation of disease in a previously $T$. gondii-seropositive pregnant woman who is immunosuppressed, or reinfection with a different genotype of the pathogen (18).

The risk of diaplacental transmission increases with gestational age, whereas the rate of clinical manifestation goes down (e13). Infection during early pregnancy with severe damage to the fetus presumably often results in abortion. No data are available on this, as embryos aborted in Germany are seldom presented for detailed examination. Especially infection during the second trimester can result in severe damage to the child, in the form of

- Micro- or hydrocephalus

- Intracerebral calcifications

- Retinochoroiditis or microphthalmia

However, this classic triad occurs in only about $5 \%$ of the affected fetuses (19).
Role of the immune system

While cellular immune mechanisms control the pathogen in infected cells, T. gondii-specific antibodies contribute to the neutralization of extracellular tachyzoites, which in women who have been previously infected helps to protect the placenta from infection.

\section{Clinically significant manifestations}

Clinically significant manifestations include congenital and ocular toxoplasmosis and, in immunosuppressed patients, organ manifestations that can often be life-threatening (encephalitis, pneumonia). 
Surveillance data from France indicate that after a first infection during pregnancy, about $12 \%$ of babies show clinical symptoms at birth (20). Severe CNS manifestations are identified on prenatal ultrasound (e14). Postnatally, infected infants may show poor feeding, seizures, or cerebral palsy as signs of CNS involvement. Although placental transmission in the third trimester is the most common, most fetuses infected at this time appear normal on ultrasound and are asymptomatic as neonates. In about $50 \%$ of patients, however, the latent infection leads to ocular toxoplasmosis, often bilateral, during the first 20 years of life, which cannot in all cases be distinguished from postnatally acquired infection (20). Sequelae include large scotomas, significant visual impairment, and blindness.

\section{Ocular toxoplasmosis}

Retinal infection with $T$. gondii is an important cause of irreversible visual impairment and is worldwide the most common cause of infectious posterior uveitis. In Germany, about $4 \%$ of uveitis manifestations have been traced to $T$. gondii infection $(16$, e15). Ocular involvement in congenital toxoplasmosis was described as early as 1923 and led to a dogmatic belief in (exclusively) mother-to-child infection. In the $1980 \mathrm{~s}$, as other routes of infection for postnatal toxoplasmosis were being identified, this belief was revised. Ocular toxoplasmosis (16, e16) follows a course of necrotizing posterior uveitis so characteristic that it is often regarded as "diagnosis at a glance." As a retinochoroiditis, the infection affects the inner layers of the retina, with persistence of the pathogen in tissue cysts and a tendency to reactivations (16, e16). In Europe 5-year recurrence rates between $54 \%$ and $63 \%$ have been reported, while the reported rates in South America are even higher (up to $80 \%)(21,22)$. Numerous risk factors have been reported, suggesting that the host-pathogen interaction is complex and, above all, immune mediated (eTable 1) $(14,21,22)$.

The importance of immune status for ocular toxoplasmosis became clear at the beginning of the AIDS epidemic. At least three alleles were associated with susceptibility to ocular manifestation in AIDS patients (e17). An HLA-B35 genotype was significantly more frequently $(p=0.01$; relative risk $[R R]=3.04)$ associated with progressive retinitis. Clinically, the presentation is often atypical and fulminant and can present a considerable diagnostic challenge requiring intraocular investigation. Repeatedly, pathogens with type I alleles have been identified (11, e18) (Figure 3).

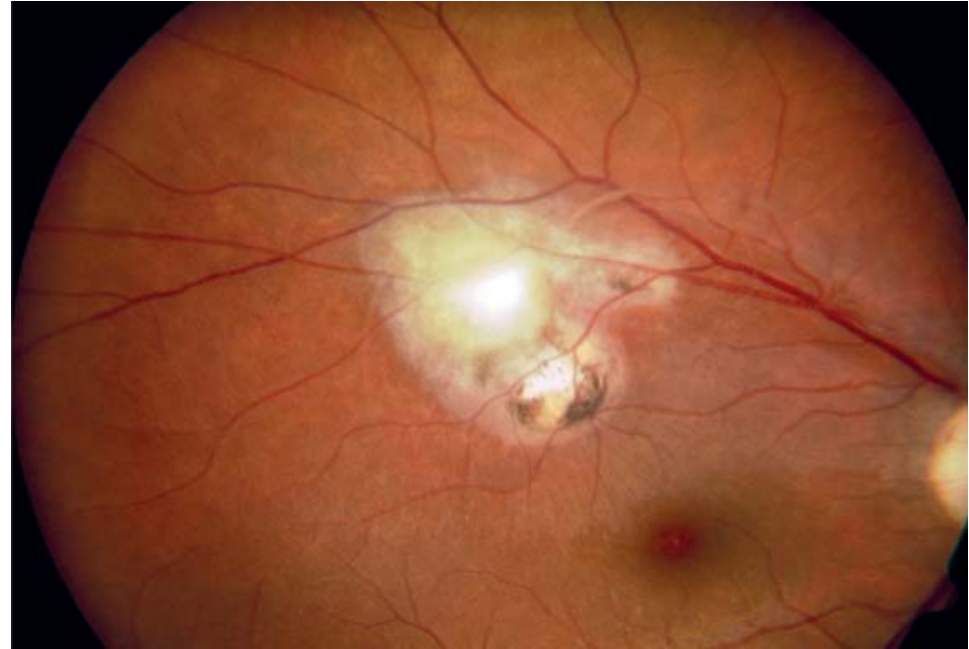

Figure 3: Retinal image of a 27-year-old woman with recurrent ocular toxoplasmosis in the right eye. Retinal necrosis can be seen above the macula, with a fresh recurrence (central "fluffy" focus) surrounded by two older, pigmented lesions. Visual acuity is reduced to 0.63 , with a deep, irreversible paracentral visual field defect (Department of Ophthalmology, Charité Campus Virchow, University Faculty of Medicine, Berlin).

\section{Immunosuppression}

\section{Infection and reactivation in transplant recipients}

The risks associated with transplantation are inadequately documented and probably underestimated (23-26). Toxoplasmosis can occur in recipients both of solid organs and of hematopoietic stem cell transplants and may be due to reactivation of a pre-existing latent infection, to a newly acquired food-borne infection, or to tissue cysts contained in a transplant (24). Recent data show a significantly lower 6-month survival rate for $T$. gondii-seropositive recipients, especially after allogeneic stem cell transplantation (38\% vs. 84\%; $\mathrm{p}<0.001)$ and liver transplantation (50\% vs. $75 \%$; $\mathrm{p}<0.001$ ) (23). The risk of transmission is especially high when a solid organ is transplanted from a recently infected donor into a seronegative recipient (Table). The risk is due to the tachyzoites present in blood, bone marrow, and various organs during parasitemia in the early phase of the infection. How long the risk of transmission persists after the donor has acquired the infection is not known for certain. Parasitemia has been shown as much as 5 weeks after the onset of symptoms. There is also a risk of transmission when transplants, especially of heart, liver, or kidney, from donors with tissue cysts due to chronic $T$. gondii infection are given to seronegative recipients. No exact figures are

\section{Ocular toxoplasmosis}

Retinal infection with $T$. gondii is an important cause of irreversible visual impairment and is worldwide the most common cause of infectious posterior uveitis. In Germany, about $4 \%$ of uveitis manifestations have been traced to $T$. gondii infection.

\section{Transplant recipients}

Toxoplasmosis can occur in recipients both of solid organs and of hematopoietic stem cell transplants and may be due to reactivation of a pre-existing latent infection, to a newly acquired food-borne infection, or to tissue cysts contained in a transplant. 
Simplified outline of toxoplasmosis treatment (adapted from [6])

\begin{tabular}{|c|c|c|}
\hline Indication & \multicolumn{2}{|l|}{ Treatment } \\
\hline $\begin{array}{l}\text { First infection } \\
\text { during pregnancy }\end{array}$ & $\begin{array}{l}\text { Up to the end of GW } 15 \\
\text { Spiramycin ( } 3.0 \mathrm{~g}=9 \mathrm{MIU} / \text { day })\end{array}$ & $\begin{array}{l}\text { From GW 16: } \\
\text { Pyrimethamine ( } 50 \mathrm{mg} \text { on day } 1 ; 25 \\
\text { mg/day from day } 2) \\
\text { plus sulfadiazine }(50 \mathrm{mg} / \mathrm{kg} \text { BW per } \\
\text { day) } \\
\text { plus folinic acid ( } 10-15 \mathrm{mg} / \text { day) }\end{array}$ \\
\hline $\begin{array}{l}\text { Congenital toxoplasmosis in } \\
\text { a neonate }\end{array}$ & \multicolumn{2}{|l|}{$\begin{array}{l}\text { For 3-12 months (depending on severity): } \\
\text { Pyrimethamine ( } 1 \mathrm{mg} / \mathrm{kg} \mathrm{BW} \text { per day) } \\
\text { plus sulfadiazine ( } 50-100 \mathrm{mg} / \mathrm{kg} \text { BW per day) } \\
\text { plus folinic acid ( } 2-3 \mathrm{mg} / \mathrm{week})\end{array}$} \\
\hline Retinochoroiditis & $\begin{array}{l}\text { Pyrimethamine ( } 50 \mathrm{mg} \text { on day } 1 ; 25 \mathrm{mg} / \text { day from } \\
\text { day } 2 \text { ) } \\
\text { plus sulfadiazine ( } 50 \mathrm{mg} / \mathrm{kg} \text { BW per day) } \\
\text { plus folinic acid ( } 10-15 \mathrm{mg} / \mathrm{day}) \\
\text { or } \\
\text { clindamycin }(1.2-2.4 \mathrm{~g} / \text { day }) \\
\text { or } \\
\text { trimethoprim/sulfamethoxazole } \\
\text { (cotrimoxazole) }(960 \mathrm{mg} / \text { day) } \\
\text { or } \\
\text { atovaquone }(3 \times 750 \mathrm{mg} / \text { day) }\end{array}$ & $\begin{array}{l}\text { Prednisone may be added* } \\
\text { (1-2 mg/kg BW per day) }\end{array}$ \\
\hline Cerebral toxoplasmosis & \multicolumn{2}{|c|}{$\begin{array}{l}\text { Pyrimethamine ( } 50 \mathrm{mg} \text { on day } 1 ; 25 \mathrm{mg} / \text { day from day } 2) \\
\text { plus sulfadiazine }(50 \mathrm{mg} / \mathrm{kg} \text { BW per day) } \\
\text { plus folinic acid ( } 10-15 \mathrm{mg} / \text { day }) \\
\text { Possible alternatives: cotrimoxazole ( } 960 \mathrm{mg} / \text { day) or atovaquone }(3 \times 750 \mathrm{mg} / \text { day })\end{array}$} \\
\hline
\end{tabular}

Note: The drugs commonly used for the treatment of toxoplasmosis—-pyrimethamine, sulfadiazine, clindamycin, and cotrimoxazole-are also licensed for use in children.

* Depending on the extent of any accompanying intraocular inflammation (vitreous involvement)

GW, Gestational week; MIU, million international units; BW, body weight

available on the incidence of $T$. gondii infection when the donor is infected and the recipient seronegative, but rates of $25 \%$ to $75 \%$ in the absence of appropriate prophylaxis have been reported (e19).

Regarding solid organs, seronegative recipients of organs from seropositive donors (especially heart/ lung) are at greatest risk (eTable 2). In such cases, the parasitemia results primarily in the infection of liver and lungs, with the typical signs of hepatitis and/or interstitial pneumonia (26).

The constellation with the highest risk for reactivation is transplantation of stem cells from a seronegative donor to a seropositive recipient (eTable 2). European centers report reactivation rates between $2.9 \%$ and $6 \%(26,27)$. Mortality rates in transplant re- cipients who develop toxoplasmosis range from $63 \%$ to $80 \%$ (26). The German Society for Hematology and Medical Oncology (DGHO, Deutsche Gesellschaft für Hämatologie und Medizinische Onkologie) has issued specific guidelines on prevention in allogeneic hematopoietic stem cell transplantation (27). Where the recipient is seropositive, long-term medical prophylaxis with cotrimoxazole is recommended. Other preventive measures in the transplantation setting include serological screening of both donors and recipients, medicinal prophylaxis, and instruction on hygiene (26). The transplant services of various countries have published recommendations on this topic, although these vary within Europe, e.g., as to the duration of chemoprophylaxis.

\section{Incidence in organ donors}

No exact figures are available on the incidence of $T$. gondii infection when the donor is infected and the recipient seronegative, but rates of $25 \%$ to $75 \%$ in the absence of appropriate prophylaxis have been reported.

\section{Mortality in transplant recipients}

Mortality rates in transplant recipients who develop toxoplasmosis range from $63 \%$ to $80 \%$. 


\section{Infection and reactivation in HIV-infected patients}

The importance of cellular immunity for control of the cyst stage and the risk of reactivation is shown by the high incidence of Toxoplasma encephalitis in AIDS patients with fewer than $200 \mathrm{CD}^{+} \mathrm{T}$ cells $/ \mu \mathrm{L}$. Before the introduction of highly active antiretroviral therapy (HAART), Toxoplasma encephalitis and Toxoplasma retinitis, present in about $30 \%$ of this risk group, were regarded as AIDS-defining opportunistic infections. Today toxoplasmosis remains the most common cause of neurological disease in HIV-positive patients, often resulting in severe pathology or even death $(29$, e20). The clinical symptoms are generally dependent on the intracerebral and intraocular localization of reactivated foci of infection.

\section{Diagnosis}

Because infection with $T$. gondii usually gives rise to nonspecific symptoms or none at all, it requires laboratory diagnosis $(30,31)$. The main investigations available are serological procedures such as ELISA and immunoblotting. The use of recombinant antigens has made an important contribution to standardization (30, e21). If an acute infection is suspected, the patient's serum should be tested for T. gondii-specific IgG and IgM antibodies (6). If organ-specific manifestations are present, local diagnostic tests are also carried out.

\section{Prenatal diagnosis and monitoring}

Especially during pregnancy, a low-positive IgM result, perhaps continuing for a long time, accompanied by the simultaneous presence of IgG antibodies - a sign of IgM persistence after a previous infection - presents a diagnostic challenge. It is assumed that the immune response with $\mathrm{TH}_{2}$ dominance, built up during pregnancy to protect the fetoplacental unit, plays an important role for this constellation. Absence IgM, on the other hand, makes a fresh infection unlikely. If high IgM and low IgG antibody titers are found, this suggests acute toxoplasmosis; the suspicion can be confirmed in a followup test 2 to 3 weeks later by a significant rise in IgG antibodies and possibly also IgA antibodies. Measuring the binding avidity of the IgG antibodies can provide a clue as to when the infection occurred: since avidity increases over the course of the immune response, demonstration of highly avid IgG antibodies - even in the presence of a weakly positive IgM finding - generally rules out an acute first infection. Low IgG avidity, on the other hand, is of no diagnostic significance (e22).

Neonates are usually investigated if the mother has shown abnormal serological findings during pregnan- cy or if there is reason to suspect congenital toxoplasmosis. The presence of specific IgM and/or IgA antibodies in the neonatal serum generally proves prenatal infection. This can be confirmed further by demonstration of IgG antibodies produced by the child (32) as well as by the persistence or increased titers of specific IgG antibodies at a later time point (e23). In addition to serological studies, other diagnostic procedures used in neonates are cranial and abdominal ultrasonography (or magnetic resonance imaging) and ophthalmological examination. In neonates showing any abnormality, the cerebrospinal fluid is also investigated (serology, polymerase chain reaction [PCR], protein level). Determination of cellular immunity parameters can also supply diagnostic evidence of prenatal infection (33). Because a negative PCR result does not rule out a pregnancyrelevant infection $(34$, e24), and early initiation of therapy is necessary even for suspected primary infection, PCR testing of amniotic fluid is rarely carried out (35).

\section{Diagnosis of ocular toxoplasmosis}

Clinical examination often shows typical retinal findings, so that no further diagnostic investigation is needed (Figure 3). In populations with a high prevalence of infection, serological tests are often unhelpful in any case. In doubtful cases, intraocular studies to show the presence of specific intraocular antibodies or PCR to show the pathogen present in the aqueous humor or the vitreous body have proved useful (16).

\section{Diagnosis in immunosuppressed patients}

Serological tests are unreliable in immunosuppressed patients, especially those who are HIV-positive. In these patients, active or reactivated infection can most reliably be shown by means of PCR (36). Depending on the clinical situation, body fluids (e.g., CSF, EDTA blood, bronchoalveolar lavage fluid) or biopsy samples (e.g., brain, lung) are suitable. Since a negative PCR result does not entirely rule out active infection, histological methods may also need to be used.

\section{Treatment}

Asymptomatic infection and uncomplicated lymphadenitis do not require treatment. Patients who become infected for the first time while pregnant and those with congenital ocular toxoplasmosis need to be treated, as do immunocompromised persons (those with HIV/AIDS or neoplastic disease) and immunodeficient transplant recipients with active or reactivated infection.

\section{Infection in HIV-infected patients}

Toxoplasmosis is the most common cause of neurological disease in HIV-positive patients, often resulting in severe pathology or even death.

\section{Abnormalities in neonates}

In addition to serological studies, other diagnostic procedures used in neonates are cranial and abdominal ultrasonography (or magnetic resonance imaging) and ophthalmological examination. 
Ocular toxoplasmosis represents a relative indication for treatment: therapy should be initiated in particular when the optic nerve or macula is threatened, when the patient has reduced visual acuity due to vitreous inflammation, or when the lesions are large ( $>1$ disk diameter) (16). The main targets of drug treatment are the tachyzoite metabolic pathways of folic acid and protein synthesis; to date the tissue cysts containing bradyzoites remain virtually impregnable. The drugs most often used are spiramycin, pyrimethamine, sulfadiazine, clindamycin, and sometimes atovaquone (Table). To minimize unwanted effects, folinic acid (not folic acid) is also given. During pregnancy, folic acid antagonists should be used only from the $16^{\text {th }}$ gestational week onwards; before this, spiramycin can be given in the attempt to prevent placental transmission. The priority is rapid initiation of combination therapy. In cases where treatment was started within 4 weeks after maternal infection, the rate of clinical manifestations in infected children was reduced from $70 \%$ to less than $20 \%$ (35). A recent prospective randomized study also found indications that combination treatment with pyrimethamine plus sulfadiazine plus folinic acid was superior to spiramycin in terms of clinical manifestations in infected newborns (37). This is especially the case when treatment is started early, within 3 weeks after maternal seroconversion during pregnancy. For ocular toxoplasmosis, in addition to the drugs already mentioned, cotrimoxazole is increasingly being used and has proved valuable for long-term prevention of recurrence $(<12$ months) in at-risk patients (e25, e26).

\section{Prevention}

Public health institutions in Germany have stated that greater awareness of preventive measures is needed to reduce the risk of infection (6, e27-e29). The main preventive measures relate to reducing the pathogen burden in the food chain; improving food hygiene; public education, especially of women of child-bearing age; and various precautions in immunosuppressed persons (including in transplantation medicine). Specific goals and interventions include the following:

- From the point of view of disease prevention, the goal should be to keep farm animals destined for human consumption free of T. gondii (e27). Veterinary data show that this can be achieved by controlling rodent pests and keeping cats out of animal sheds (38).

- Developing vaccines against the excretion of oocysts by infected cats could reduce exposure to oocysts. Live vaccines (Toxovax) are currently being used in sheep to reduce the development of tissue cysts (e30).

- Physicians and health authorities (especially in the eastern federal states of Germany, because of the higher rates of infection there) should be made more aware of the toxoplasmosis issue. Educational prevention programs (adequate cooking of meat and thorough washing of fruit and vegetables [e28, e29]) can only reduce the rate of new infections, however, not eliminate existing cases of infection (e31).

- Screening for T. gondii antibodies during pregnancy, as carried out for example in France and Austria, is not currently performed in Germany (e32). However, antenatal care under the prevailing German guidelines (Mutterschafts-Richtlinien) does include serological tests when there are grounds for suspecting toxoplasmosis (39). In one retrospective study of 685 pregnant women, early diagnosis and treatment of acute infection in the mother led to a sharp reduction in the disease burden of newborns (35). Since recent data do not support the assumption hitherto that screening prevents only a small number of cases (5), these two facts suggest that the value of a screening program needs to be reassessed (40, e33).

- In transplantation medicine, especially allogeneic hematopoietic stem cell transplantation, the preventive measures recommended by the professional societies should be observed: these include screening of donors and recipients, drug prophylaxis, and instructions regarding hygiene (27).

\section{Conflict of interest statement}

Professor Gross has received fees for the preparation of scientific conferences and reimbursement of travel and accommodation costs from MSD.

The remaining authors declare that no conflict of interest exists..

Manuscript received on 15 November 2018, revised version accepted on 23 May 2019

\section{Dedication}

We dedicate this article to the memory of our valued colleague and researcher into toxoplasmosis, Ermanno Candolfi (Strasbourg), who was taken from us much too soon.

Translated from the original German by Kersti Wagstaff.

\section{References}

1. Montoya JG, Liesenfeld O: Toxoplasmosis. Lancet 2004; 363 : 1965-76.

2. Havelaar AH, Kirk MD, Torgerson PR, et al.: World Health Organization global estimates and regional comparisons of the burden of foodborne disease in 2010. PLoS Med 2015; 12: e1001923.

3. Schlüter D, Däubener W, Schares G, Groß U, Pleyer U, Lüder C: Animals are key to human toxoplasmosis. Int J Med Microbiol 2014; 304: 917-29.

\section{Diagnosis in immunosuppressed patients}

Because serological tests are unreliable in immunosuppressed patients, the use of PCR is recommended for direct demonstration of the parasite.

\section{Treatment}

Asymptomatic infection and uncomplicated lymphadenitis do not require treatment. Patients who become infected for the first time while pregnant and those with congenital ocular toxoplasmosis need to be treated. 
4. Torgerson PR, Mastroiacovo P: The global burden of congenital toxoplasmosis: a systematic review. Bull World Health Organ 2013; 91: 501-8.

5. Wilking $\mathrm{H}$, Thamm M, Stark K, Aebischer T, Seeber F: Prevalence, incidence estimations, and risk factors of Toxoplasma gondii infection in Germany: a representative, cross-sectional, serological study. Sci Rep 2016; 6: 22551.

6. Robert Koch-Institut: RKI-Ratgeber Toxoplasmose. Epid Bull 2018; 42: 451-7.

7. Fernandez C, Jaimes J, Ortiz MC, Ramirez JD: Host and Toxoplasma gondii genetic and non-genetic factors influencing the development of ocular toxoplasmosis: a systematic review. Infect Genet Evol 2016; 44: 199-209.

8. Rodrigues KF, Faria e Arantes TE, Muccioli C, Neto JL, Pinheiro MM: Incidence of Toxoplasma retinochoroiditis in patients with ankylosing spondylitis after using TNF-alpha blockers. Parasitol Int 2013; 62: 272-5.

9. Rico-Torres CP, Vargas-Villavicencio JA, Correa D: Is Toxoplasma gondii type related to clinical outcome in human congenital infection? Systematic and critical review. Eur J Clin Microbiol Infect Dis 2016; 35: 1079-88.

10. Herrmann DC, Maksimov P, Hotop A, et al.: Genotyping of samples from German patients with ocular, cerebral and systemic toxoplasmosis reveals a predominance of Toxoplasma gondii type II. Int J Med Microbiol 2014; 304: 911-6.

11. Vallochi AL, Muccioli C, Martins MC, Silveira C, Belfort R, Rizzo LV: The genotype of Toxoplasma gondii strains causing ocular toxoplasmosis in humans in Brazil. Am J Ophthalmol 2005; 139: 350-1.

12. Meenken $C$, Rothova A, de Waal LP, van der Horst AR, Mesman BJ, Kijlstra A HLA typing in congenital toxoplasmosis. Br J Ophthalmol 1995; 79: 494-7.

13. Luma HN, Tchaleu BC, Mapoure YN, et al.: Toxoplasma encephalitis in HIV/ AIDS patients admitted to the Douala general hospital between 2004 and 2009: a cross sectional study. BMC Res Notes 2013; 6: 146.

14. Garweg JG, Scherrer JN, Halberstadt M: Recurrence characteristics in European patients with ocular toxoplasmosis. Br J Ophthalmol 2008; 92 1253-6.

15. El Bissati K, Levigne P, Lykins J, et al.: Global initiative for congenital toxoplasmosis: an observational and international comparative clinical analysis. Emerg Microbes Infect 2018; 7: 165 .

16. Maenz M, Schlüter D, Liesenfeld O, Schares G, Groß U, Pleyer U: Ocular toxoplasmosis past, present and new aspects of an old disease. Prog Retin Eye Res 2014; 39: 77-106

17. Parlog A, Schluter D, Dunay IR: Toxoplasma gondii-induced neuronal alterations. Parasite Immunol 2015; 37: 159-70.

18. Elbez-Rubinstein A Ajzenberg D, Darde ML et al.: Congenital toxoplasmosis and reinfection during pregnancy: case report, strain characterization, experimental model of reinfection, and review. J Infect Dis 2009; 199: 280-5.

19. Thiebaut R, Leproust S, Chene G, Gilbert R: Effectiveness of prenatal treatment for congenital toxoplasmosis: a meta-analysis of individual patients' data. Lancet 2007; 369: 115-22.

20. Villena I, Ancelle T, Delmas C, et al.: Congenital toxoplasmosis in France in 2007: first results from a national surveillance system. Euro Surveill 2010; 15.

21. de-la-Torre A, Rios-Cadavid AC, Cardozo-Garcia CM, Gomez-Marin JE: Frequency and factors associated with recurrences of ocular toxoplasmosis in a referral centre in Colombia. Br J Ophthalmol 2009; 93: 1001-4.

22. Holland GN, Crespi CM, ten Dam-van Loon N, et al.: Analysis of recurrence patterns associated with toxoplasmic retinochoroiditis. Am J Ophthalmol 2008; 145: 1007-13.

23. Robert-Gangneux F, Meroni V, Dupont D, et al.: Toxoplasmosis in transplant recipients, Europe, 2010-2014. Emerg Infect Dis 2018; 24: 1497-504.

24. Prestes DP, Mendes C, Batista MV, et al.: A case-series of Toxoplasmosis in hematopoietic stem cell transplantation: still a concern for endemic countries. Bone Marrow Transplant. 2018;5:1336-9.

25. Mele A, Paterson PJ, Prentice HG, Leoni P, Kibbler CC: Toxoplasmosis in bone marrow transplantation: a report of two cases and systematic review of the literature. Bone Marrow Transplant 2002; 29: 691-8.
26. Isa F, Saito K, Huang YT, et al: Implementation of molecular surveillance after a cluster of fatal toxoplasmosis at 2 neighboring transplant centers. Clin Infect Dis 2016; 63: 565-8.

27. Ullmann AJ, Schmidt-Hieber M, Bertz H, et al.: Infectious diseases in allogeneic haematopoietic stem cell transplantation: prevention and prophylaxis strategy guidelines 2016. Ann Hematol 2016; 95: 1435-55

28. Silva AC, Rodrigues BS, Micheletti AM, et al.: Neuropathology of AIDS: an autopsy review of 284 cases from Brazil comparing the findings pre- and postHAART (Highly Active Antiretroviral Therapy) and pre- and postmortem correlation. AIDS Res Treat 2012; 2012: 186850.

29. Ford N, Meintjes G, Calmy A, et al.: Managing advanced HIV disease in a public health approach. Clin Infect Dis 2018; 66: 106-10.

30. Dard C, Fricker-Hidalgo H, Brenier-Pinchart MP, Pelloux H: Relevance of and new developments in serology for toxoplasmosis. Trends Parasitol 2016; 32: 492-506

31. Pomares C, Montoya JG: Laboratory diagnosis of congenital toxoplasmosis. J Clin Microbiol 2016; 54: 2448-54.

32. Groß U, Lüder CG, Hendgen V, et al.: Comparative immunoglobulin $\mathrm{G}$ antibody profiles between mother and child (CGMC test) for early diagnosis of congenital toxoplasmosis. J Clin Microbiol 2000; 38: 3619-22.

33. Chapey E, Wallon M, Debize G, Rabilloud M, Peyron F: Diagnosis of congenital toxoplasmosis by using a whole-blood gamma interferon release assay. J Clin Microbiol 2010; 48: 41-5.

34. Prusa AR, Kasper DC, Pollak A, Olischar M, Gleiss A, Hayde M: Amniocentesis for the detection of congenital toxoplasmosis: results from the nationwide Austrian prenatal screening program. Clin Microbiol Infect 2015; 21: 191.e1-8.

35. Hotop A, Hlobil H, Groß U: Efficacy of rapid treatment initiation following primary Toxoplasma gondii infection during pregnancy. Clin Infect Dis 2012; 54 : 1545-52.

36. Villard O, Cimon B, L'Ollivier C, et al.: Serological diagnosis of Toxoplasma gondii infection: recommendations from the French National Reference Cente for Toxoplasmosis. Diagn Microbiol Infect Dis 2016; 84: 22-33.

37. Mandelbrot L, Kieffer F, Sitta R, et al.: Prenatal therapy with pyrimethamine + sulfadiazine vs spiramycin to reduce placental transmission of toxoplasmosis: a multicenter, randomized trial. Am J Obstet Gynecol 2018; 219: 386.e1-.e9.

38. Kijlstra A, Jongert E: Toxoplasma-safe meat: close to reality? Trends in Parasitology 2009; 25: 18-22.

39. Richtlinien des Gemeinsamen Bundesausschusses über die ärztliche Betreuung während der Schwangerschaft und nach der Entbindung. Bundesanzeiger 2016: 60a. www.g-ba.de/richtlinien/19/

40. Lange AE, Thyrian JR, Wetzka S, et al.: The impact of socioeconomic factors on the efficiency of voluntary toxoplasmosis screening during pregnancy: a population-based study. BMC Pregnancy Childbirth 2016; 16: 197.

\section{Corresponding author:}

Prof. Uwe Pleyer

Augenklinik, Charité Campus Virchow, Universitätsmedizin Berlin

Corporate Member of Freie Universität Berlin

Humboldt-Universität zu Berlin und Berlin Institute of Health

Augustenburger Platz 1, 13353 Berlin, Germany

uwe.pleyer@charite.de

\section{Cite this as:}

Pleyer U, Gross U, Schlüter D, Wilking $\mathrm{H}$, Seeber $\mathrm{F}$

Toxoplasmosis in Germany-epidemiology, diagnosis, risk factors, and treatment

Dtsch Arztebl Int 2019; 116: 435-44. DOl: 10.3238/arztebl.2019.0435

\section{Supplementary material}

For eReferences please refer to:

www.aerzteblatt-international.de/ref2519

eFigures, eTables:

www.aerzteblatt-international.de/19m0435 


\section{CME credit for this unit can be obtained via cme.aerzteblatt.de until 15 September 2019.} Only one answer is possible per question. Please select the answer that is most appropriate.

\section{Question 1}

To which group of pathogens does Toxoplasma gondii belong?
a) Bacteria
b) Viruses
c) Prions
d) Nematodes
e) Protozoa

Question 2

Which treatment regimen is used in a patient with retinochoroiditis?
a) Tetracycline + folic acid
b) Pyrimethamine + sulfadiazine + folinic acid
c) Vancomycin + fluconazole
d) Amoxicillin + fluconazole + atovaquone
e) Spiramycin + atovaquone

Question 3

By what percentage does seroprevalence rise with every year of age in Germany from 18 onwards?
a) $0.1 \%$
b) $0.5 \%$
c) $1 \%$
d) $2 \%$
e) $5 \%$

\section{Question 4}

How is $T$. gondii probably most frequently transmitted in Germany?

a) By the eating or handling of undercooked meat

b) By contaminated blood products

c) By contaminated drinking water

d) By mother-to-child transmission

e) By aerosols

\section{Further information on CME}

- Participation in the CME certification program is possible only via the Internet: cme.aerzteblatt.de. This unit can be accessed until 15 September 2019. Submissions by letter, e-mail or fax cannot be considered.

- The following CME units can still be accessed for credit:

- „Pleural Effusion in Adults-Etiology, Diagnosis, and Treatment“ (issue 21/2019) until 18 August 2019;

- „Hearing Impairment in Old Age_Detection, Treatment, and Associated Risks" (issue17/2019) until 21 July 2019;

- „Otitis Externa-Investigation and Evidence-Based Treatment" (issue 13/2019) until 23 June 2019.

- This article has been certified by the North Rhine Academy for Continuing Medical Education. Participants in the CME program can manage their CME points with their 15-digit "uniform CME number" (einheitliche Fortbildungsnummer, EFN), which is found on the CME card

(8027XXXXXXXXXXXX). The EFN must be stated during registration on www.aerzteblatt.de ("Mein DÄ") or else entered in "Meine Daten," and the participant must agree to communication of the results.
Question 5

Which animals are definitive hosts of $T$. gondii and a possible source of infection for human beings?
a) Dogs
b) Foxes
c) Hares
d) Cats
e) Pigeons

Question 6

In which federal states in Germany are most cases of T. gondii infection diagnosed?

a) Schleswig-Holstein + Bavaria

b) Lower Saxony+ North Rhine-Westphalia

c) Berlin + Brandenburg

d) Baden-Württemberg + Hesse

e) Rhineland-Palatinate + Saarland

Question 7

In which organ does $T$. gondii most frequently persist?
a) Liver
b) Pancreas
c) Spleen
d) Kidney
e) Brain

Question 8

Which of the following is a typical malformation found in a child whose mother was infected by $T$. gondii during the second trimester of pregnancy?
a) Horseshoe kidney
b) Hypoplasia of the liver
c) Hydrocephalus
d) Spina bifida
e) Macrosomia

Question 9

Which of the following is an indication for treatment of a T. gondii infection?

a) Demonstration of $\lg G$ in a patient with acute conjunctivitis

b) Interstitial pneumonia in an immunocompetent patient

c) Lymphadenitis in a patient with acute infection

d) Seronegative patient who has received a liver transplant

e) Seroconverted pregnant woman with a markedly raised

T. gondii-specific lgM titer

\section{Question 10}

What is the mortality rate in transplant recipients who develop toxoplasmosis?
a) $3 \%$ to $20 \%$
b) $23 \%$ to $40 \%$
c) $43 \%$ to $60 \%$
d) $63 \%$ to $80 \%$
e) $83 \%$ to $100 \%$

- Participation is possible only via the Internet: cme.aerzteblatt.de 
Supplementary material to:

\title{
Toxoplasmosis in Germany
}

\author{
Epidemiology, Diagnosis, Risk factors, and Treatment
}

by Uwe Pleyer, Uwe Gross, Dirk Schlüter, Henrik Wilking, and Frank Seeber

Dtsch Arztebl Int 2019; 116: 435-44. DOI: 10.3238/arztebl.2019.0435

\section{eReferences}

e1. Cassini A, Colzani E, Pini A, et al.: Impact of infectious diseases on population health using incidence-based disability-adjusted life years (DALYs): results from the Burden of Communicable Diseases in Europe study, European Union and European Economic Area countries, 2009 to 2013. Euro Surveill 2018; 23: 17-00454.

e2. Suijkerbuijk AWM, van Gils PF, Bonacic Marinovic AA, et al.: The design of a social cost-benefit analysis of preventive interventions for toxoplasmosis: an example of the One Health approach. Zoonoses Public Health 2018; 65: 185-94.

e3. da Silva AJ, Moser M: Toxoplasmosis. Image \#3421 i; Centers for Disease Control and Prevention's Public Health Image Library 2002 https://phil.cdc.gov/Details.aspx?pid=3421 (last accessed on 19 May 2019).

e4. Bowie WR, King AS, Werker DH, et al.: Outbreak of toxoplasmosis associated with municipal drinking water. The BC Toxoplasma Investigation Team. Lancet 1997; 350: 173-7.

e5. Jones JL, Dubey JP: Waterborne toxoplasmosis - recent developments. Exp Parasitol 2010; 124: 10-25

e6. Lass A, Szostakowska B, Korzeniewski K, Karanis P: The first detection of Toxoplasma gondii DNA in environmental air samples using gelatine filters, real-time PCR and loop-mediated isothermal (LAMP) assays: qualitative and quantitative analysis. Parasitology 2017; 144: 1791-801.

e7. Robert-Gangneux F, Darde ML: Epidemiology of and diagnostic strategies for toxoplasmosis. Clin Microbiol Rev 2012; 25: 264-96.

e8. Bremer v, Bocter N, Rehmet S, Klein G, Breuer T, Ammon A: Consumption, knowledge, and handling of raw meat: a representative cross-sectional survey in Germany, March 2001. J Food Prot 2005; 68: 785-9.

e9. Rosner BM, Stark K, Höhle M, Werber D: Risk factors for sporadic Yersinia enterocolitica infections, Germany 2009-2010. Epidemiol Infect 2012; 140: 1738-47.

e10. Xiao J, Yolken RH: Strain hypothesis of Toxoplasma gondii infection on the outcome of human diseases. Acta Physiol (Oxf) 2015; 213 828-45.

e11. Gonzalez-Vicent M, Diaz MA, Sevilla J, Madero L: Cerebral toxoplasmosis following etanercept treatment for idiophatic pneumonia syndrome after autologous peripheral blood progenitor cell transplantation (PBPCT). Ann Hematol 2003; 82: 649-53.

e12. Lassoued S, Zabraniecki L, Marin F, Billey T: Toxoplasmic chorioretinitis and antitumor necrosis factor treatment in rheumatoid arthritis. Semin Arthritis Rheum 2007; 36: 262-3.

e13. Desmonts G, Couvreur J: [Congenital toxoplasmosis. Prospective study of the outcome of pregnancy in 542 women with toxoplasmosis acquired during pregnancy]. Ann Pediatr (Paris) 1984; 31 : 805-9.

e14. Vökt CA, Visca E, Tercanli S: Sonographische Befunde bei maternofetalen Infektionen. Ther Umschau 2008; 65: 667-74.

e15. Jakob E, Reuland MS, Mackensen F, et al.: Uveitis subtypes in a German interdisciplinary uveitis center-analysis of 1916 patients J Rheumatol 2009; 36: 127-36.

e16. Butler NJ, Furtado JM, Winthrop KL, Smith JR: Ocular toxoplasmosis II: clinical features, pathology and management. Clin Exp Ophthalmol 2013; 41: 95-108.

e17. Demarco AL, Rodrigues Mde L, Figueiredo JF, et al.: Susceptibility to toxoplasmic retinochoroiditis is associated with HLA alleles reported to be implicated with rapid progression to AIDS. Dis Markers 2012; 33: 309-12

e18. Grigg ME, Ganatra J, Boothroyd JC, Margolis TP: Unusual abundance of atypical strains associated with human ocular toxoplasmosis. J Infect Dis 2001; 184: 633-9.

e19. Derouin F, Pelloux H: Prevention of toxoplasmosis in transplant patients. Clin Microbiol Infect 2008; 14: 1089-101. e20. Weiss LM, Dubey JP: Toxoplasmosis: a history of clinical observations. Int J Parasitol 2009; 39: 895-901.

e21. Holec-Gasior L: Toxoplasma gondii recombinant antigens as tools for serodiagnosis of human toxoplasmosis: current status of studies. Clin Vaccine Immunol 2013; 20: 1343-51.

e22. Reiter-Owona I: Laboratory diagnosis of toxoplasmosis possibilities and limitations. J Lab Med 2005; 29: 439-45.

e23. Lebech M, Joynson DH, Seitz HM, et al.: Classification system and case definitions of Toxoplasma gondii infection in immunocompetent pregnant women and their congenitally infected offspring. European Research Network on Congenital Toxoplasmosis. Eur J Clin Microbiol Infect Dis 1996; 15: 799-805.

e24. Romand S, Wallon M, Franck J, Thulliez P, Peyron F, Dumon H: Prenatal diagnosis using polymerase chain reaction on amniotic fluid for congenital toxoplasmosis. Obstet Gynecol 2001; 97 : 296-300.

e25. Connolly MP, Haitsma G, Hernandez AV, Vidal JE: Systematic review and meta-analysis of secondary prophylaxis for prevention of HIV-related toxoplasmic encephalitis relapse using trimethoprimsulfamethoxazole. Pathog Glob Health 2017; 111: 327-31.

e26. Fernandes Felix JP, Cavalcanti Lira RP, Cosimo AB, Cardeal da Costa RL, Nascimento MA, Leite Arieta CE: TrimethoprimSulfamethoxazole versus placebo in reducing the risk of toxoplasmic retinochoroiditis recurrences: a three-year follow-up. Am J Ophthalmol 2016; 170: 176-82

e27. Opsteegh M, Kortbeek TM, Havelaar AH, van der Giessen JW: Intervention strategies to reduce human Toxoplasma gondii disease burden. Clin Infect Dis 2015; 60: 101-7.

e28. Bundeszentrum für Ernährung: Listeriose und Toxoplasmose Sicher essen in der Schwangerschaft. 2017. www.ble-medienservice. de/0346/listeriose-und-toxoplasmose-sicher-essen-in-der-schwangerschaft (last accessed on 19 May 2019).

e29. Bundesinstitut für Risikobewertung: Schutz vor Toxoplasmose. Verbrauchertipp 2017. https://mobil.bfr.bund.de/cm/350/ verbrauchertipps_schutz_vor_toxoplasmose.pdf (last accessed on 19 May 2019).

e30. Verma R, Khanna P: Development of Toxoplasma gondii vaccine: a global challenge. Hum Vaccin Immunother 2013; 9: 291-3.

e31. Kullenberg de Gaudry D, Grede N, Motschall E, Lins S: Analysis of German nutrition brochures for pregnant women with evidencebased patient information criteria. Patient Educ Couns 2015; 98 : 207-12.

e32. Prusa AR, Kasper DC, Sawers L, Walter E, Hayde M, Stillwaggon E: Congenital toxoplasmosis in Austria: prenatal screening for prevention is cost-saving. PLoS Negl Trop Dis 2017; 11: e0005648.

e33. Zylka-Menhorn V. Toxoplasmose-Test Argumente für ein Screening. Dtsch Arztebl 2013; 110: 446

e34. Jokelainen P, Murat JB, Nielsen HV: Direct genetic characterization of Toxoplasma gondii from clinical samples from Denmark: not only genotypes II and III. Eur J Clin Microbiol Infect Dis 2018; 37: $579-86$.

e35. Shobab L, Pleyer U, Johnsen J, et al.: Toxoplasma serotype is associated with development of ocular toxoplasmosis. J Infect Dis 2013; 208: 1520-8.

e36. Witola WH, Liu SR, Montpetit A, et al.: ALOX12 in human toxoplasmosis. Infect Immun 2014; 82: 2670-9

e37. Witola WH, Mui E, Hargrave A, et al.: NALP1 influences susceptibility to human congenital toxoplasmosis, proinflammatory cytokine response, and fate of Toxoplasma gondii-infected monocytic cells. Infect Immun 2011; 79: 756-66.

e38. Jamieson SE, de Roubaix LA, Cortina-Borja M, et al.: Genetic and epigenetic factors at COL2A1 and ABCA4 influence clinical outcome in congenital toxoplasmosis. PLoS One 2008; 3: e2285.

e39. Takakura A, Tessler HH, Goldstein DA, et al.: Viral retinitis following intraocular or periocular corticosteroid administration: a case series 
and comprehensive review of the literature. Ocul Immunol Inflamm 2014; 22: 175-82.

e40. Sauer A, Pfaff AW, Villard O, et al.: Interleukin 17A as an effective target for anti-inflammatory and antiparasitic treatment of toxoplasmic uveitis. J Infect Dis 2012; 206: 1319-29.

e41. Dutra MS, Bela SR, Peixoto-Rangel AL, et al.: Association of a NOD2 gene polymorphism and T-helper 17 cells with presumed ocular toxoplasmosis. J Infect Dis 2013; 207: 152-63.

e42. Albuquerque MC, Aleixo AL, Benchimol El, et al.: The IFN-gamma +874 T/A gene polymorphism is associated with retinochoroiditis toxoplasmosis susceptibility. Mem Inst Oswaldo Cruz 2009; 104 451-5.

e43. Peixe RG, Boechat MS, Rangel AL, Rosa RF, Petzl-Erler ML, Bahia-Oliveira LM: Single nucleotide polymorphisms in the interferon gamma gene are associated with distinct types of retinochoroidal scar lesions presumably caused by Toxoplasma gondii infection. Mem Inst Oswaldo Cruz 2014; 109: 99-107.

e44. Naranjo-Galvis CA, de-la-Torre A, Mantilla-Muriel LE, et al.: Genetic polymorphisms in cytokine genes in Colombian patients with ocular toxoplasmosis. Infect Immun 2018; 86. e45. Cordeiro CA, Moreira PR, Andrade MS, et al.: Interleukin-10 gene polymorphism $(-1082 \mathrm{G} / \mathrm{A})$ is associated with toxoplasmic retinochoroiditis. Invest Ophthalmol Vis Sci 2008; 49: 1979-82.

e46. Cordeiro CA, Moreira PR, Bessa TF, et al.: Interleukin- 6 gene polymorphism $(-174 \mathrm{G} / \mathrm{C})$ is associated with toxoplasmic retinochoroiditis. Acta Ophthalmol 2013; 91: e311-4.

e47. Cordeiro CA, Moreira PR, Costa GC, et al.: Interleukin-1 gene polymorphisms and toxoplasmic retinochoroiditis. Mol Vis 2008; 14 1845-9.

e48. Peixoto-Rangel AL, Miller EN, Castellucci L, et al.: Candidate gene analysis of ocular toxoplasmosis in Brazil: evidence for a role for toll-like receptor 9 (TLR9). Mem Inst Oswaldo Cruz 2009; 104 1187-90.

e49. de Faria Junior GM, Ayo CM, de Oliveira AP, et al.: CCR5 chemokine receptor gene polymorphisms in ocular toxoplasmosis. Acta Trop 2018; 178: 276-80.

e50. Jamieson SE, Peixoto-Rangel AL, Hargrave AC, et al.: Evidence for associations between the purinergic receptor P2X(7) (P2RX7) and toxoplasmosis. Genes Immun 2010; 11: 374-83. 


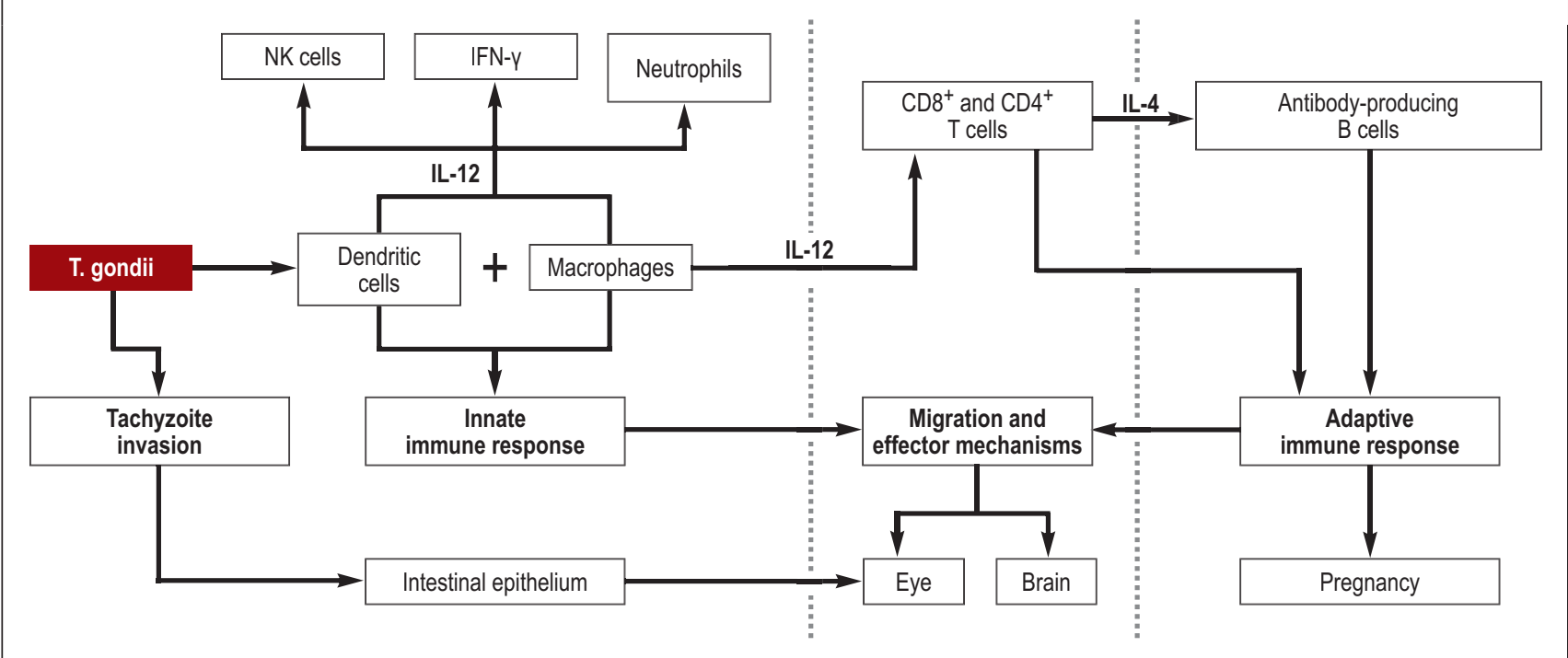

Simplified representation of dissemination and immune response in $T$. gondii infection. Once oral infection has occurred, $T$. gondii penetrates the intestinal epithelium and becomes disseminated, in part intracellularly, in dendritic cells and macrophages in the host and infects many organs. In the gut, macrophages and dendritic cells recognize intracellular tachyzoites and/or conserved structural features of the parasite (e.g., glycosylphosphatidylinositol, parasitic DNA and RNA) by means of toll-like receptors (TLR9) and other pattern-associated recognition receptors. The activated macrophages and dendritic cells produce IL-12, which induces interferon- $\gamma$ production of natural killer (NK) cells and type 1 innate lymphoid cells. Alongside this activation of the innate immune system, parasite-specific CD4 ${ }^{+}$and $\mathrm{CD}^{+} \mathrm{T}$ cells develop, which also produce IFN-y and are activated by dendritic cells and/or macrophages. IFN-y induces antiparasitic effector mechanisms in infected cells, such as production of GTPases and indoleamine-2,3-dioxygenase. Likewise, the cytotoxic effect of NK and CD8 ${ }^{+} \mathrm{T}$ cells contributes to the elimination of infected cells. Through the production of IL-4, T cells activate B cells, which contribute to protection by producing T. gondii-specific antibodies. 
eTABLE 1

Risk factors affecting the course of a T. gondii infection*

\begin{tabular}{|c|c|c|c|}
\hline Infection route and clinical manifestation & T. gondit-specific risk factors & Quantitative measurement & $\begin{array}{l}\text { Referencel } \\
\text { source }\end{array}$ \\
\hline \multicolumn{4}{|l|}{ Congenital } \\
\hline & $\begin{array}{l}\text { Genotype I versus genotypes II + III with } \\
\text { severe clinical course }\end{array}$ & $\begin{array}{l}86.9 \text { versus } 72.9 \% \text {; OR } 2.47,95 \% \mathrm{Cl}[1.1 \text {; } \\
5.4] \text { ) }\end{array}$ & (9) \\
\hline \multicolumn{4}{|l|}{ Postnatal } \\
\hline Cerebral toxoplasmosis & Increased incidence of genotype II & $\begin{array}{l}\text { Descriptive case series; no concrete data } \\
\text { available }\end{array}$ & (10) \\
\hline Ocular toxoplasmosis & $\begin{array}{l}\text { Increased severity of retinitis with genotypes } \\
\text { I, III, or atypical pathogens } \\
\text { Atypical genotypes may lead more often than } \\
\text { type II to ocular toxoplasmosis and more } \\
\text { frequent recurrences }\end{array}$ & $\begin{array}{l}\text { Descriptive case series; no concrete data } \\
\text { available } \\
\text { OR 10.0,95\% CI [3.4; 40.8]; }(p<0.0001) \\
(p=0.037)\end{array}$ & $\begin{array}{l}(7,11)(\mathrm{e} 18, \\
\mathrm{e} 34, \mathrm{e} 35)\end{array}$ \\
\hline Infection route and clinical manifestation & Host-specific factors & Quantitative measurement & $\begin{array}{l}\text { Referencel } \\
\text { source }\end{array}$ \\
\hline \multicolumn{4}{|l|}{ Congenital } \\
\hline & $\begin{array}{l}\text { NALP1 gene polymorphisms are associated } \\
\text { with congenital toxoplasmosis }\end{array}$ & $\begin{array}{l}\text { NALP1 rs8081261 }(p<0.00268) \\
\text { NALP1 rs11652907 }(p<0.02)\end{array}$ & $(\mathrm{e} 36, \mathrm{e} 37)$ \\
\hline \multirow[t]{3}{*}{ Ocular toxoplasmosis } & $\begin{array}{l}\text { HLA-B62 increases susceptibility to bilateral } \\
\text { eye involvement }\end{array}$ & OR $2.8(p=0.006)$ & (12) \\
\hline & $\begin{array}{l}\text { Retina-specific ABCA4 transporter increases } \\
\text { susceptibility to congenital eye involvement }\end{array}$ & OR $2.06,95 \% \mathrm{Cl}[1.14 ; 3.73](p=0.017)$ & (e38) \\
\hline & $\begin{array}{l}\text { Alpha-1 type II collagen COL2A1 increases } \\
\text { susceptibility to congenital eye involvement }\end{array}$ & OR $1.79,95 \% \mathrm{Cl}[1.06 ; 3.04](p=0.031)$ & (e38) \\
\hline $\begin{array}{l}\text { Cerebral toxoplasmosis (reactivated } \\
\text { T. gondii encephalitis) }\end{array}$ & $\begin{array}{l}\text { High risk of reactivation in } \mathrm{CD4}^{+} \mathrm{T} \text { cells } \\
<100 / \mu \mathrm{L} \text { (e.g., after heart or stem cell } \\
\text { transplantation) }\end{array}$ & OR $26.8,95 \% \mathrm{Cl}[1.5 ; 16.9](p=0.001)$ & (13) \\
\hline \multicolumn{4}{|l|}{ Postnatal } \\
\hline \multirow[t]{7}{*}{ Ocular toxoplasmosis } & $\begin{array}{l}\text { Age }<21 \text { years and male sex show higher } \\
\text { tendency to recurrence }\end{array}$ & $\begin{array}{l}\text { Descriptive case series showing increased } \\
\text { recurrence in patients below } 21 \text { years of age } \\
(p<0.05)\end{array}$ & (14) \\
\hline & Age $>50$ years: larger/atypical retinal lesions & Descriptive case series & (e39) \\
\hline & $\begin{array}{l}\text { Intraocular overproduction of } \\
\text { proinflammatory cytokines (IL-17) }\end{array}$ & Descriptive case series & $(\mathrm{e} 40, \mathrm{e} 41)$ \\
\hline & $\begin{array}{l}\text { Increased susceptibility to ocular } \\
\text { toxoplasmosis in the presence of gene } \\
\text { polymorphisms for these cytokines: } \\
\text { Interferon-y } \\
\text { (A/T + T/T allele) } \\
\text { Interferon-y } \\
\text { (GG rs2069718) } \\
\text { Interferon-y } \\
\text { (874T/A) } \\
\text { IL-10 (1082A/AA+AG) } \\
\text { IL-10 (1082 G/A) } \\
\text { IL-6 (174 G/C) } \\
\text { IL-1A }(889 \mathrm{C} / \mathrm{T})\end{array}$ & $\begin{array}{l}\text { OR 2.62, 95\% Cl }[1.1 ; 6.19](p=0.014) \\
\text { OR 3.3, 95\% Cl }[1.604 ; 6.835](p=0.0014) \\
\text { OR 4.2, 95\% Cl }[2.48 ; 7.12](p=0.003) \\
\text { OR 2.55, 95\% Cl }[1.11 ; 5.55](p=0.01) \\
\text { OR 5.27, 95\% Cl }[3.18 ; 8.74](p=0.001) \\
\text { OR 6.62 (95\% Cl not provided) }(p=0.01) \\
\text { OR 5.46 (95\% Cl not provided) }(p=0.02)\end{array}$ & $\begin{array}{l}(\mathrm{e} 42) \\
(\mathrm{e} 43) \\
(\mathrm{e} 44) \\
\\
(\mathrm{e} 45) \\
(\mathrm{e} 44) \\
(\mathrm{e} 46) \\
(\mathrm{e} 47)\end{array}$ \\
\hline & Toll-like receptor 9 & OR 4.23, 95\% Cl $[1.6 ; 30.8](p<0.001)$ & (e48) \\
\hline & Chemokine receptor CCR5 & OR $2.98(95 \% \mathrm{Cl}$ not provided $)(p=0.018)$ & (e49) \\
\hline & $\begin{array}{l}\text { Protective effect for ocular toxoplasmosis } \\
\text { Purinergic receptor } \mathrm{P} 2 \mathrm{X} 7\end{array}$ & OR $0.27,95 \%$ Cl $[0.09 ; 0.80](p<0.01)$ & (e50) \\
\hline
\end{tabular}


MEDICINE

Infection route and clinical manifestation $\quad$ T. gondit-specific risk factors

HLA B35 (in AIDS patients) increased risk of reactivation
Quantitative measurement

OR $3.04(95 \% \mathrm{Cl}$ not provided $)(p=0.01)$
Reference

source

(e17)

The following distinctions are made:

a) Route of infection (congenital versus postnatal)

b) Clinical manifestation (cerebral versus ocular)

c) Pathogen-specific and host-specific factors

Data on frequency distribution and risks are taken from the original publications.

$95 \% \mathrm{Cl}, 95 \%$ confidence interval; OR, odds ratio 
eTABLE 2

Risk pattern and prophylactic measures for T. gondii infection in transplantation medicine*

\begin{tabular}{|c|c|c|c|c|}
\hline & Risk of transmission & Risk of reactivation & Onset of symptoms & Measures/prophylaxis \\
\hline \multicolumn{5}{|c|}{ Organ or tissue transplantation } \\
\hline Heart or heart-lung & High for mismatch D+R- & Low in $\mathrm{R}^{+}$ & $25-195$ days & Cotrimoxazole for prevention \\
\hline Liver & Low for mismatch $D+R$ - & Low in $\mathrm{R}+$ & Median 24 days & Cotrimoxazole for prevention \\
\hline Kidney & Low for mismatch $D+R$ - & Low in $\mathrm{R}^{+}$ & Median 19 days & Not known \\
\hline Bowel & Low for mismatch D+R- & Not known & & Not known \\
\hline Cornea & No risk & & & \\
\hline \multicolumn{5}{|c|}{ Stem cell transplantation } \\
\hline Autologous & No risk & Very low in $\mathrm{R}+$ & $9-120$ days & Not known \\
\hline Allogeneic & Low & $\begin{array}{l}\text { High in } \mathrm{R}+\text {, independent of } \\
\text { donor serology } \\
\text { Increased risk in cord blood } \\
\text { stem cell transplantation }\end{array}$ & Median 62 days & $\begin{array}{l}\text { Cotrimoxazole for prevention (already } \\
\text { used for Pneumocystis prophylaxis) } \\
\text { Alternatively, pyrimethamine-sulfa- } \\
\text { doxine from month } 1 \text { to month } 6 \text { after } \\
\text { stem cell transplantation } \\
\text { Continued or initiated anew if GVHD or } \\
\text { long-term immunosuppression occurs }\end{array}$ \\
\hline
\end{tabular}

${ }^{*}$ Adapted from (e19)

D, donor; GVHD, graft-versus-host disease; R, recipient; +, T. gondii seropositive; -, T. gondii seronegative 